\section{Stability of the fluvial system}

The Fluvial System. By S. A. Schumm. Pp. 338. (Wiley: London, New York and Toronto, 1977.) $£ 16.50$.

THE knowledge of fluviatile matters advances so rapidly that some aspects of it require re-appraisal every decade. Yet there still remain a few fundamental aspects which need stating fully anew, among them the inherent stability or instability of the fluvial system as a whole. This integral approach has increased in importance in recent historic times in proportion as the activities of mankind have impinged upon natural processes and caused unexpected reactions. Dr Schumm is a recognised authority on fluvial backlash and here takes the opportunity of incorporating some of his hitherto unpublished observational and experimental studies on the problem.

Wisely refraining from trying to outdo existing large textbooks on open-channel hydraulics, geomorphology, sedimentology and stratigraphy, he presents an account of concepts on the internal stability or instability of drainage basins. He provides details of the validity of these concepts and expounds on their wide practical applications. As would be expected, his approach is refreshingly empirical and stems from a true realisation of the sort of practical problems that all too often face civil engineers, economic geologists and any other Earth scientists who tamper with the Earth's surface.

The practicability of the text is increased by emphasis throughout on features and events of moderate scale and duration or on intermediate spans of time that tend to be neglected by geologists and geomorphologists who so often look more for long-term effects. Thus, landforms are essentially ignored to make space for details on, for example, changes in channel character and the distribution of sediment types in valleys, fans and alluvial plains.

The fluvial system is viewed--as it should always be - as a unitary, indivisible whole, and the text is organised to leave a complete fluvial picture in the reader's mind. After brief introductory

- In the review of The Lymphocyte (Nature,

9 March, 272, 193; 1978), line 4 should read: "it is easy to judge harshly as it", and not as shown. chapters on the general geomorphic concepts and the variables and rates of change in fluvial systems, there follows an excellent chapter on climatic change and paleohydrology, both Quaternary and earlicr. The main body of the text (pp57-320) contains a tripartite analysis of the drainage basin, starting with the drainage divide or sediment source area, and proceeding through valleys and valley fills in the transfer zone, to depositional sites on the piedmont and coastal plain. The concepts and detailed arguments are summarised in a concluding chapter on the fluvial system, particularly from the point of view of soil conservationists, land managers, river engineers, geomorphologists and geologists.

Secmingly anomalous features of the fluvial landscape or their erratic development through time are explained by three concepts: intrinsic geomorphic thresholds; complex response; and episodic erosion and deposition. These, the author

\section{Research on the eukaryotic chromosome}

The Eukaryotic Chromosome. By C. J. Bostock and A. T. Sumner. Pp. 525. (Elsevier/North-Holland: Amsterdam, New York and Oxford, 1977.) \$79.75; Dfl. 195.

THE cell nucleus, once seen as a bag of loosely-organised material, is now emerging as a highly structured region: "A place for everything, and everything in its place", to quote Samuel Smiles out of context. This book brings together the results (up to the end of 1976) of the most recent wave of chromosome research, which has originated partly from the sophistication of techniques for the analysis of their molecular biology, and partly from the discovery of their gross substructure, as manifest by the various banding techniques. There has not hitherto been (as the authors discovered to their surprise) a comprehensive and up-to-date review of the subject. There is admittedly no right moment to bring out any review of a rapidly expanding field; and important discoveries will incvitably be made before it appears in print-in this case most notably the recent discovery that genes are not continuous but contain inserts of material of unknown function. But the book is as complete and up-todate as is possible with a work of such high quality.

The authors collate information from any research on eukaryotic chromosomes which sheds light on their fundamental anatomy and physiology. It does not try to deal with comparative chromosomal contends, provide a means of developing a better understanding of the dynamics of landform evolution and, perhaps more importantly, a means of identifying within a landscape those components of the system that are inherently or incipiently unstable but are amenable to man's control. The same approach would also form a basis for predicting the future behaviour of existing unstable landforms, which is one of the major aims of modern geomorphologists.

This volume, with its generous illustrations and lists of latest references, will be welcomed also by Earth scientists generally. It fills an important niche in fluvial literature, and its lucid style and clear exposition place it well within the range of students in any form of higher education.

Robert P. Beckinsale

Robert Beckinsale is a Special Supernumerary Fellow at University College, Oxford, UK.

studies in relation to speciation, chromosomal pathology in man, or the details of gene assignment to human chromosomes (although the principles underlying this are discussed); this information is available elsewhere. Nor do they deal with every variant of the eukaryotic chromosome (for example, the microchromosomes of birds are not mentioned), although the specialised polytene and lampbrush chromosomes are considered in great detail because of the light they shed on chromosomal function.

The book starts with an introduction which includes the fundamental $\mathrm{C}$-value paradox (why so little of the DNA present can be genetically active). Chapters follow on chromosomal DNA; RNA and proteins, and their molecular interaction in chromatin; the interphase nucleus in relation to spatial organisation; relationship of chromosomes to nuclear membrane; chromosome replication; polytene chromosomes; mitotic and meiotic chromosomes; and lampbrush chromosomes. The last four chapters cover substructure and banding, location of DNA sequences and genes, damage and repair, and models of chromosome structure.

The book is clearly and homogeneously written; cach chapter starts with an introduction for the uninitiated. It is comprehensive, accurate, and produced to the highest standard. There are many diagrams and photographs (including electron micrographs), and these are beautifully clear. Inevitably, the price is enormous. But it pays to buy the best, and this is it.

E. H. R. Ford

E. H. R. Ford is Lecturer in Anatomy at the University of Cambridge, UK. 